\section{CITAÇÃO}

Félix, F., Amandi, C. (2018)

Marcas de ondulação produzidas pelo vento,

Rev. Ciência Elem., V6 (04):080.

doi.org/10.24927/rce2018.080

\section{EDITOR}

José Ferreira Gomes,

Universidade do Porto

\section{EDITOR CONVIDADO}

Jorge Manuel Canhoto,

Universidade de Coimbra

\section{RECEBIDO EM}

21 de setembro de 2018

\section{ACEITE EM}

21 de setembro de 2018

\section{PUBLICADO EM}

04 de dezembro de 2018

\section{COPYRIGHT}

(C) Casa das Ciências 2018.

Este artigo é de acesso livre, distribuído sob licença Creative Commons com a designação CC-BY-NC-SA 4.0, que permite a utilização e a partilha para fins não comerciais, desde que citado o autor e a fonte original do artigo.

\title{
Marcas de ondulação produzidas pelo vento
}

in imagem.casadasciencias.org

As marcas de ondulação formam um padrão repetitivo. Mas, tal como a repetição, as variações são inúmeras, dependentes da ação do vento sobre a superfície.

Esta ação - a repetição - é uma função central à atividade humana. Esta reincidência intrínseca à sua origem, formaliza uma espécie de dispositivo para apreender determinado conhecimento ou mecanismo e que, quando adquirido, permite identidade e estabilidade ao pensamento.

A repetição não é o fazer igual, portanto. Tal como as ondulações produzidas pelo vento, repetir é uma experiência dinâmica sobre algo e que no seu retorno, insiste na multiplicação de possibilidades. Ou seja, de encontrar no mesmo percurso, novas hipóteses e destinos diferentes.

Relativamente ao seu processo criativo, o artista William Anastasi é muito claro quanto a esta competência:

(...) "Da quinta vez que ouvi a 4a sinfonia de Mozart gostei mais dela do que a primeira vez. Então fiquei com a ideia que talvez a arte fosse da mesma maneira"

Cláudia Amandi

I2ADS/FBAUP/ Universidade do Porto
Costumo percorrer a orla costeira do concelho de Peniche com o objetivo de captar imagens associadas à divulgação do património natural deste território. Se as fotografias reúnem potencial didático-pedagógico e em termos estéticos são adequadas, submeto-as ao Banco de Imagens da Casa das Ciências, pois talvez possam ser úteis a outros colegas. De um modo geral, tento mostrar a sua utilidade remetendo para os conteúdos suscetíveis de serem explorados em sala de aula. Para mim, este trabalho tem sido muito proveitoso, quer pela satisfação em dar a conhecer o concelho de onde sou natural, quer pelas aprendizagens efetuadas neste contexto, nomeadamente pela integração das sugestões disponibilizadas pelos editores.

0 sistema praia-duna que se estende da Península de Peniche ao Baleal, dado o seu bom estado de conservação, possibilita a recolha de imagens de rara beleza. Neste caso, podem observar-se marcas de ondulação produzidas pelo vento sobre a superfície dunar.

\section{Francisco Fidalgo Félix}

Escola Secundária de Peniche

rce.casadasciencias.org

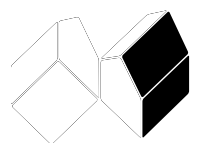




\section{REVISTA DE CIÊNCIA ELEMENTAR}

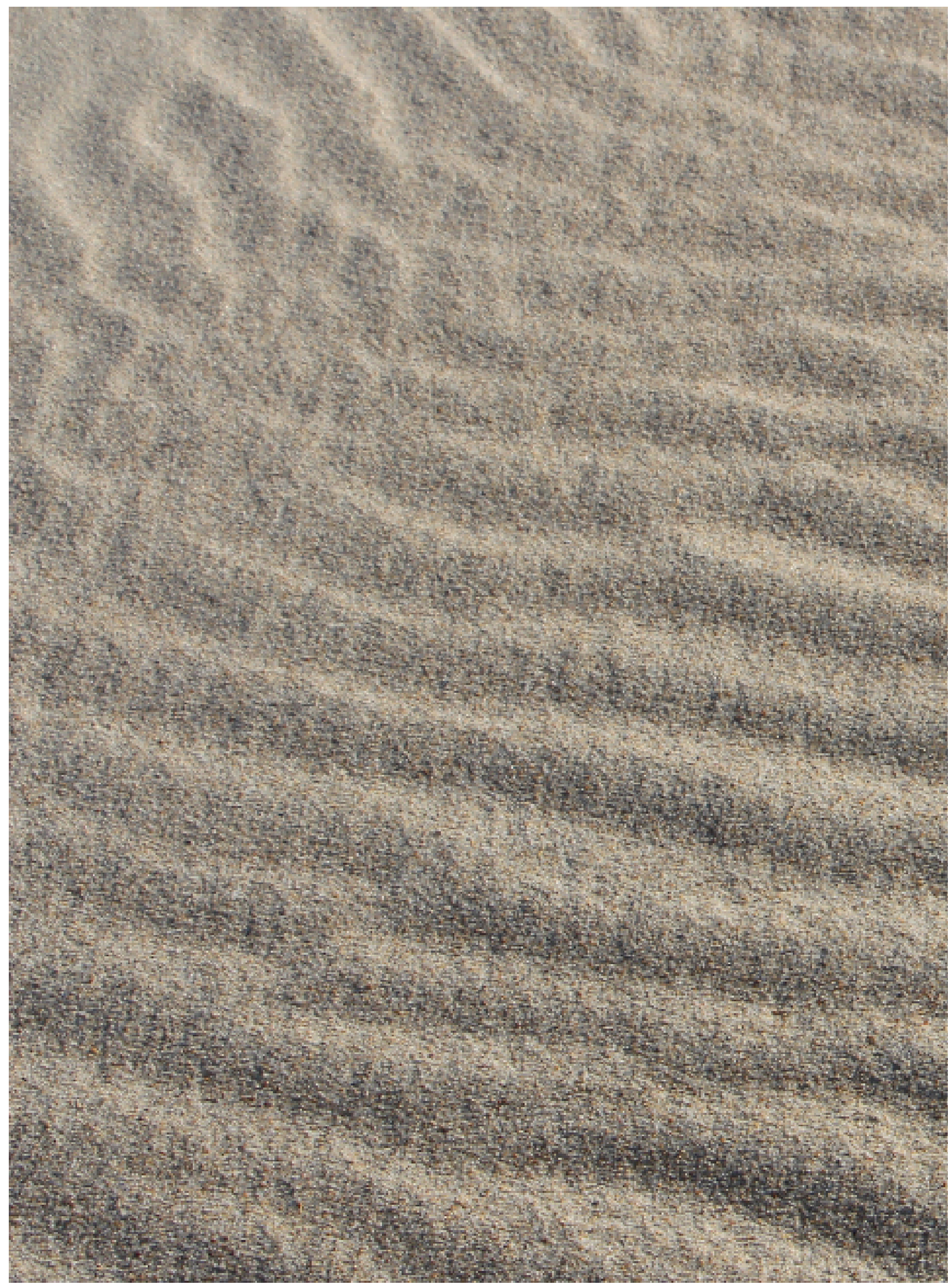

